\title{
Colitis caused by food allergy in infants
}

\author{
S M Hill, P J Milla
}

\begin{abstract}
Thirteen infants with eosinophilic colitis caused by food allergy were reviewed after five to 10 years. By the age of 5 years most foods were tolerated. The colon was normal in the one child re-examined. There was an atopic association, but no family history of classical inflammatory bowel disease. Allergic colitis is a temporary disorder of early childhood.
\end{abstract}

Food allergy is important in most children attending hospital with colitis during the first two years of life. ${ }^{1}$ The natural history of the disease is uncertain. It might progress to classical inflammatory bowel disease (in particular Crohn's disease) so becoming an intermittent but life long problem, or it may completely resolve (as does food sensitive enteropathy).

The aim of this study was to review the 13 children who have presented to our clinic with colitis caused by food allergy since 1977 who are now over 5 years old.

\section{Patients and methods}

Thirteen patients (11 boys and two girls) were studied. All had presented with chronic diarrhoea containing blood and mucus before 2 years of age (median age 2 months, range 1 week-20 months). Four were breast fed by their mothers who were taking normal diets, seven were given cows' milk based formula feeds, and two were given mixed diets. Stool cultures grew no pathogens.

On colonoscopic examination there was patchy colonic erythema in all cases, and histological examination of biopsy specimens from erythematous areas showed inflammatory cell infiltrates in the lamina propria in which eosinophils and plasma cells predominated. One child had a single crypt abscess.

After colonoscopy cows' milk and eggs were excluded from their diets, and the diarrhoea resolved within 48 hours. Seven thrived on soya milk (Cow and Gate formula), but in five symptoms recurred so a chicken based feed (Cow and Gate Chix) was substituted. One continued to breast feed and the mother excluded cows' milk and egg from her diet and took oral sodium cromoglycate. One child also received a short course of hydrocortisone enemas as he had a severe colitis with crypt abscess. Repeat colonoscopies were normal. Early challenge with offending foods was avoided as one child had a severe reaction that required blood transfusion.
Seven of the children (54\%) gave a personal, and $12(92 \%)$ gave a family, history of atopy in at least one first degree relative. Symptoms included asthma, eczema, hay fever, urticaria, angio-oedema, and rhinitis, and three had siblings with colitis caused by food allergy. Serum IgA concentration was low in one child and at the low end of the normal range in nine others.

Follow up information obtained at outpatient review included whether symptoms recurred when foods were introduced into the diet, and the age at which offending foods were tolerated. Children were challenged with these foods from 18 months of age, one food at a time. Weight gain was observed, and development of further atopic symptoms recorded. Further investigations included repeat colonoscopy in one patient.

\section{Results}

Seven children developed diarrhoea when they were given one or more new foods. The foods were beef $(n=3)$, wheat $(n=3)$, white flour $(n=1)$, fish $(n=2)$, pork $(n=2)$, and goats' milk $(n=1)$. Once established on appropriate diets all children remained healthy and thrived without medication.

Cows' milk was successfully reintroduced to some children between the ages of 18 months and 8 years (median 4 ) (table). One child did not tolerate it at the age of $2 \cdot 5$ years, and was lost to follow up. Seven children disliked drinking milk, and developed loose stools if they did so excessively, but they tolerated it in cooking.

Most other foods were tolerated over the same age range, but in no specific order, and some are still not tolerated (table).

Colonoscopy was repeated in the first patient diagnosed when tolerating a normal diet and the bowel was macroscopically and histologically normal. Further colonoscopies in the other patients were not clinically indicated.

Two children developed new allergic symptoms (one rhinitis and one asthma), and eczema resolved in six.

\section{Discussion}

Food allergy is an important cause of infantile colitis in children referred to our clinic and seems to be benign with an excellent prognosis if treated correctly. ${ }^{1}$ The features that distinguish colitis caused by food allergy from classical inflammatory bowel disease are macroscopic appearances at colonoscopy and
Institute of Child

30 Guilford Street London WCIN $1 \mathrm{EH}$

Accepted 29 August 1989 
Ages at which particular foods were tolerated by patients who initially presented with colitis caused by food allergy

\begin{tabular}{|c|c|c|c|c|}
\hline $\begin{array}{l}\text { Case } \\
\text { No }\end{array}$ & $\begin{array}{l}\text { Age at time } \\
\text { of study } \\
\text { (years) }\end{array}$ & $\begin{array}{l}\text { Food } \\
\text { introduced }\end{array}$ & $\begin{array}{l}\text { Age at which } \\
\text { food tolerated } \\
\text { (years) }\end{array}$ & $\begin{array}{l}\text { Food not } \\
\text { tolerated at } \\
\text { time of study }\end{array}$ \\
\hline 1 & 7 & $\begin{array}{l}\text { Eggs } \\
\text { Milk }\end{array}$ & $\begin{array}{l}2 \\
2 \cdot 5\end{array}$ & None \\
\hline 2 & 10 & $\begin{array}{l}\text { Soya, wheat } \\
\text { Fish, eggs, milk }\end{array}$ & $\begin{array}{l}4 \\
7 \cdot 5\end{array}$ & None \\
\hline 3 & 7 & $\begin{array}{l}\text { Eggs } \\
\text { Milk }\end{array}$ & $\begin{array}{l}4 \cdot 2 \\
5 \cdot 2\end{array}$ & None \\
\hline 4 & 10 & $\begin{array}{l}\text { White flour } \\
\text { Eggs } \\
\text { Pork } \\
\text { Milk }\end{array}$ & $\begin{array}{l}3 \\
3 \cdot 6 \\
5 \\
6\end{array}$ & Beef \\
\hline 5 & 6 & $\begin{array}{l}\text { Soya } \\
\text { Milk } \\
\text { Eggs }\end{array}$ & $\begin{array}{l}3 \cdot 5 \\
4 \cdot 1 \\
5\end{array}$ & None \\
\hline 6 & 10 & $\begin{array}{l}\text { Eggs } \\
\text { Beef } \\
\text { Soya } \\
\text { Milk }\end{array}$ & $\begin{array}{l}4 \\
5 \cdot 2 \\
5 \cdot 7 \\
6 \cdot 3\end{array}$ & None \\
\hline 7 & 8 & $\begin{array}{l}\text { Milk } \\
\text { Eggs } \\
\text { Wheat }\end{array}$ & $\begin{array}{l}1 \cdot 8 \\
2 \cdot 5 \\
3 \cdot 5\end{array}$ & None \\
\hline 8 & 5 & $\begin{array}{l}\text { Eggs } \\
\text { Milk }\end{array}$ & $\begin{array}{l}4 \\
5 \cdot 2\end{array}$ & Fish \\
\hline 9 & $7 \cdot 3$ & $\begin{array}{l}\text { Eggs, soya, goats' milk } \\
\text { Milk }\end{array}$ & $\begin{array}{l}4 \\
6\end{array}$ & None \\
\hline $\begin{array}{l}10 \\
11 \\
12\end{array}$ & $\begin{array}{l}6 \cdot 8 \\
5 \\
5\end{array}$ & $\begin{array}{l}\text { Pork, milk, eggs } \\
\text { Eggs, milk } \\
\text { Soya, eggs, milk }\end{array}$ & $\begin{array}{l}4 \\
3 \\
3 \cdot 5\end{array}$ & $\begin{array}{l}\text { Beef, wheat } \\
\text { None } \\
\text { None }\end{array}$ \\
\hline
\end{tabular}

histological features of colonic biopsy specimens; complete remission on an appropriate exclusion diet; association with atopy ${ }^{12}$; and no family history of inflammatory bowel disease. ${ }^{1}$ Compliance with exclusion diets was apparently excellent, as clinical symptoms and colonic abnormalities resolved completely. Although the typical findings on colonoscopy of patchy, regional erythema and microscopic eosinophilic and plasma cell infiltration of the lamina propria (possibly with oedema) distinguish this condition from other types of colitis, eosinophilic colitis without infection has been described in older age groups. These, however, have not shown immediate resolution of symptoms on exclusion diets. ${ }^{3}$ Remission of chronic inflammatory bowel disease when taking exclusion diets has been reported, and it is possible that some patients have a chronic colitis caused by food allergy. ${ }^{2}$ The single crypt abscess seen in a colonic biopsy specimen of one infant was probably related to the length of time he had had the disease (eight months), ${ }^{4}$ and has been noted previously in colitis caused by food allergy. $^{5}$

The wide age range over which different foods were tolerated by individual patients meant that the only logical way of reintroducing foods was to offer them at regular intervals, and every six months seemed appropriate. No particular food could be offered first as there was no typical order in which foods were tolerated. Most children tolerated most foods by the age of 5 years (mean age for milk 4.5 years) so they had not yet started school. Variations in the ages at which tolerance was gained was similar to those of children who 'grow out of' eczema or asthma.

The high incidence of personal or family history of atopy $(69 \%$ of patients and $92 \%$ of first degree relatives) has previously been described, ${ }^{246}$ as has the unequal sex ratio (11 of 13 patients were boys). ${ }^{6}$ More boys may have low serum $\operatorname{IgA}$ concentrations, which is possibly relevant to the pathogenesis of the disease. $^{2}$ The onset while breast feeding and resolution of symptoms with maternal dietary manipulation have also been previously described. ${ }^{24}$

We have shown that colitis caused by food allergy is an eosinophilic colitis in atopic infants. It is well defined, both clinically and histologically, and there is complete remission on an appropriate exclusion diet. It may occur in breast fed babies. The food intolerance seems to be temporary, as by 5 years of age previously offending foods are usually tolerated and all our group could tolerate cows' milk by the age of 8 years. None have relapsed or developed other gastrointestinal problems, particularly classical inflammatory bowel disease.

1 Jenkins HR, Pincott JR, Soothill JF, Milla PJ, Harries JT. Food allergy: the major cause of infantile colitis. Arch Dis Child 1984;59:326-9.

2 Milla PJ. Food allergic colitis in infants. In: Dobbing J, ed. Food intolerance. London: Ballière Tindall, 1987:101-7. 3 Naylor AR. Eosinophilic colitis. Dis Colon Rectum 1985;28: 615-8.

4 Lake AM, Whitington P, Hamilton SR. Dietary proteininduced colitis in breast-fed infants. $\mathcal{F}$ Pediatr 1982;101: 906-10.

5 Halpin TC, Byrne WJ, Ament ME. Colitis, persistent diarrhoea, and soya protein intolerance. $\mathcal{F}$ Pediatr 1977;91: 404-7.

6 Gryboski JD. Gastrointestinal milk allergy in infants. Pediatrics 1967;40:354-60. 